\title{
Model Pengembangan Sistem Informasi Pendaftaran Online Pasien Pada Klinik Gigi Dentika Berbasis User Centred Design
}

\author{
Jully Triansyah $^{1}$, Rusma Insan Nurachim ${ }^{2}$, Susi Ermawati ${ }^{1}$, Sandra Dewi Saraswati ${ }^{3}$, Vivi Maria ${ }^{1}$ \\ ${ }^{1}$ Fakultas Teknik, Prodi Teknik Informatika, Universitas Muhammadiyah Tangerang, Banten, Indonesia \\ ${ }^{2}$ Fakultas Teknologi Informasi, Prodi Sistem Informasi Akuntansi, Universitas Bina Sarana Informatika, Jakarta, Indonesia \\ ${ }^{3}$ Prodi Teknik Informatika, Universitas Nusa Mandiri, Jakarta, Indonesia \\ Email: 1trian.juli@ft-umt.ac.id, ${ }^{2}$ rusma.rsc@bsi.ac.id, ${ }^{3}$ susi.ermawati64@gmail.com, ${ }^{4}$ sandra.sww@ @nusamandiri.ac.id, \\ ${ }^{4}$ vivi.vvm@bsi.ac.id \\ Submitted: 03/05/2021; Accepted: 24/05/2021; Published: 30/05/2021
}

\begin{abstract}
Abstrak-Dalam era berbasis online saat ini, penggunaan website dalam melakukan prosedur pendaftaran pasien sangat bermanfaat. Klinik Gigi Dentika merupakan salah satu klinik gigi yang berada di wilayah Tangerang dan memiliki cukup banyak pasien. Dalam prosedur pendaftaran pasien untuk pemeriksaan masih menggunakan sistem manual yaitu pasien datang langsung dan menunggu antrean pemeriksaan. Hal ini dirasa kurang efektif karena dapat terjadi antrean panjang di satu waktu tertentu. Pendaftaran online pasien berbasis web ini adalah untuk memudahkan pasien dalam melakukan pendaftaran diri pad asaat akan melakukan pengobatan atau perawatan gigitanpa harus datang terlebih dahulu ke klinik. Keuntungan lain ialah memudahkan staff administrasi klinik dalam melayani pendaftaran pasien, meningkatkan efisiensi waktu dalam hal pelayanan terhadap pasien dan memudahkan dalam pengelolaan datapasien. Metode User Centered Design $(U C D)$ merupakan salah satu metode yang tepat untuk memecahkan masalah pendaftaran pasien di Klinik Gigi Dentika. Metode ini melihat dari sisi kebutuhan user atau pengguna dalam perancangan sebuah sistem informasi. Hasil dari penelitian ini adalah sebuah website yang dapat di akses oleh pasien untuk melakukan pendaftaran pemeriksaan.
\end{abstract}

Kata Kunci: Sistem Informasi; Pasien; Metode User Centered Design (UCD); Website

Abstract-In today's online-based era, the use of websites in carrying out patient registration procedures is very useful. Dental Clinic Dentika is one of the dental clinics located in the Tangerang area and has quite a number of patients. In the procedure for registering patients for examination, they still use a manual system, where patients come directly and wait in line for the examination. This is deemed ineffective because long lines can occur at a certain time. This web-based online patient registration is to make it easier for patients to register themselves when they are going to take medication or dental care without having to come to the clinic first. Another advantage is that it makes it easier for clinical administrative staff to serve patient registration, increases time efficiency in terms of patient care and facilitates patient data management. The User Centered Design (UCD) method is one of the right methods to solve the problem of patient registration at the Dentika Dental Clinic. This method looks at the needs of the user or users in designing an information system. The result of this study is a website that can be accessed by patients to register for the examination.

Keywords: Information Systems; Patients; User Centered Design (UCD) Method; Website

\section{PENDAHULUAN}

Perkembangan teknologi informasi dan komunikasi yang sedemikian cepatnya telah membawa dunia memasuki era baru yang lebih cepat dari yang pernah dibayangkan sebelumnya. Perkembangan teknologi ini membawa perubahan dalam berbagai bidang kehidupan manusia, salah satu kemajuan dari teknologi adalah dihasilkannya komputer sebaga ialat bantu manusiadalam melakukan pekerjaan dan juga internet sebagai sarana komunikasi penghubung yang digunakan melalui komputer. Perkembangan teknologi informasi pada zaman ini sangat berpengaruh pada kemajuan suatu organisasi teknologi informasi yang memberikan sebuah kecepatandan keakuratan dalam melakukan pengolahan data bila dibandingkan dengan cara manual, tuntunan pelayanan informasi dan pengolahan informasi secara terintegrasi menjadi sangat penting di setiap lembaga, termasuk di klinik.

Klinik Gigi Dentika merupakan sebuah klinik yang bergerakdibidang jasa pengobatan dan perawatan gigi yang ada di wilayah Cikupa Tangerang, Klinik Gigi Dentika merupakan klinik khusus gigi yang melayani pasien dari anak-anak, dewasa hingga orangtua. Dan masalah yang ada pada klinik gigi dentika yaitu pendaftaraan yang ada pada klinik gigi dentika saat ini masih dengan cara pasien datang secara langsung ke klinik gigi dentika untukmendaftarkan diri dan mendapatkan nomor antrian sesuai kedatangan pasien sehingga membutuhkan waktu yang cukup lama karena harus menunggu antrian pengobatan dan perawatan gigi terlebih dahulu [1]. Karena kurangnya informasi dari pihak klinik mengakibatkan pasien datang disaat klinik tutup atau libur, hal ini menurunkan kualitas pelayanan kepada pasien [2]. Pengelolaan data pasien di klinik gigi masih bersifat manual sehingga pelayanan pasien menjadi lambat dan rekam pasien sering hilang atau tidak ditemukan [3].

Solusi yang dibutuhkan untuk menangani permasalah tersebut adalah dengan perancangan sistem informasi berbasis web dengan menerapkan metode User Centered Design (UCD) dengan tujuan dapat mengatasi masalah ketidakmampuan pengguna dalam menggunakan sistem dan diharapkan pengguna mampu mengetahui fungsi sistem hanya dalam sekali pakai [4]. 


\section{METODE PENELITIAN}

\subsection{Tahapan Penelitian}

Dalam penelitian ini dilakukan beberapa tahapan penelitian. Adapun tahapan metode penelitian dalam pengumpulan data yang dilakukan adalah Observasi (Observation) yaitu mengamati langsung permasalahan yang terjadi pada Klinik Gigi Dentika, Wawancara (Interview) yaitu mewawancara pihak-pihak yang berkaitan dengan penelitian guna mendapatkan informasi valid yang dibutuhkan dan Studi Pustaka (Library Research) yaitu penelusuran literatur-literatur yang relevan untuk menyempurnakan penelitian ini.

\subsection{Metode User Centred Design (UCD)}

User Centred Design (UCD) disebut human centered design. Human centered design merupakan suatu metode yang dimanfaatkan untuk pengembangan sistem secara interaktif yang bertujuan untuk membuat sebuah perangkat lunak atau sistem [5]-[7]. Dalam metode UCD, ada 4 tahapan yang harus dilalui secara iterasi seperti pada gambar 1

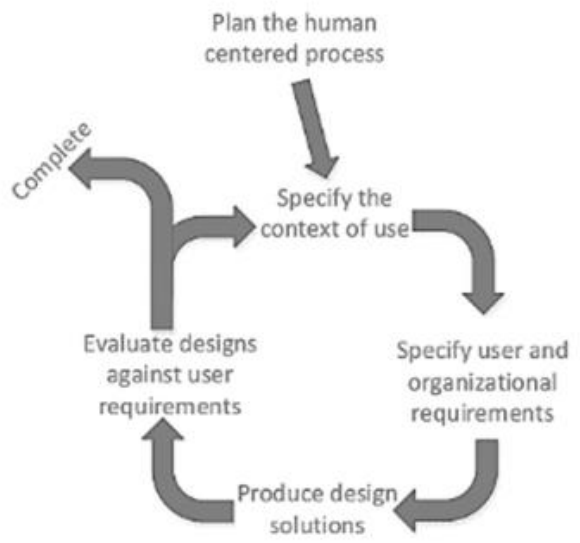

Keterangan gambar:

Gambar 1. Tahapan dalam Metode UCD

1. Specify the context of use

Mengindentifikasi pengguna yang akan menggunakan aplikasi.

2. Specify User and Organizational Requirements

Mengidentifikasi apa saja yang pengguna butuhkan terhadap aplikasi.

3. Produce Design Solutions

Merancang desain sebagai bagian dari mewujudkan solusi dari aplikasi yang sedang dirancang.

4. Evaluate Design

Mengevaluasi desain yang telah selesai dilakukan pada tahapan yang dibuat sebelumnya.

\section{HASIL DAN PEMBAHASAN}

Analisa sistem dilakukan dengan terlebih dahulu melihat kebutuhan dari prosedur. Analisa kebutuhan sistem dilakukan untuk mengidentifikasi kebutuhan yang diperlukan dalam membangun program aplikasi.

\subsection{Penerapan Metode UCD}

a. Analisa Kebutuhan Masukan

Analisa kebutuhan masukan yang berupa data pasien.

b. Analisa Kebutuhan Proses

Analisa kebutuhan proses yang berupa pemodelan data. Analisis ini dimaksud untuk mengambarkan prosesproses yang terjadi didalam program aplikasi melalui sebuah pemodelan. Pemodelan yang digunakan oleh penulis adalah pendekatan terstruktur dengan pemakaian Unified Modelling Language(UML) yang juga telah dijelaskan pada landasan teori [8].

c. Analisa Kebutuhan Keluaran

Analisis kebutuhan keluaran berupa tampilan program aplikasi yang akan dirancang pada perancangan antarmuka program aplikasi ini menggunakan perangkat lunak pendukung Balsamiq Mocups. Program aplikasi ini nantinya akan dijalankan pada windows 10 yang disesuaikan dengan sistem operasi yang digunakan oleh penulis dalam penelitian ini 
Desain Perancangan Sistem Menggunakan UML

\section{a. Use Case Diagram}

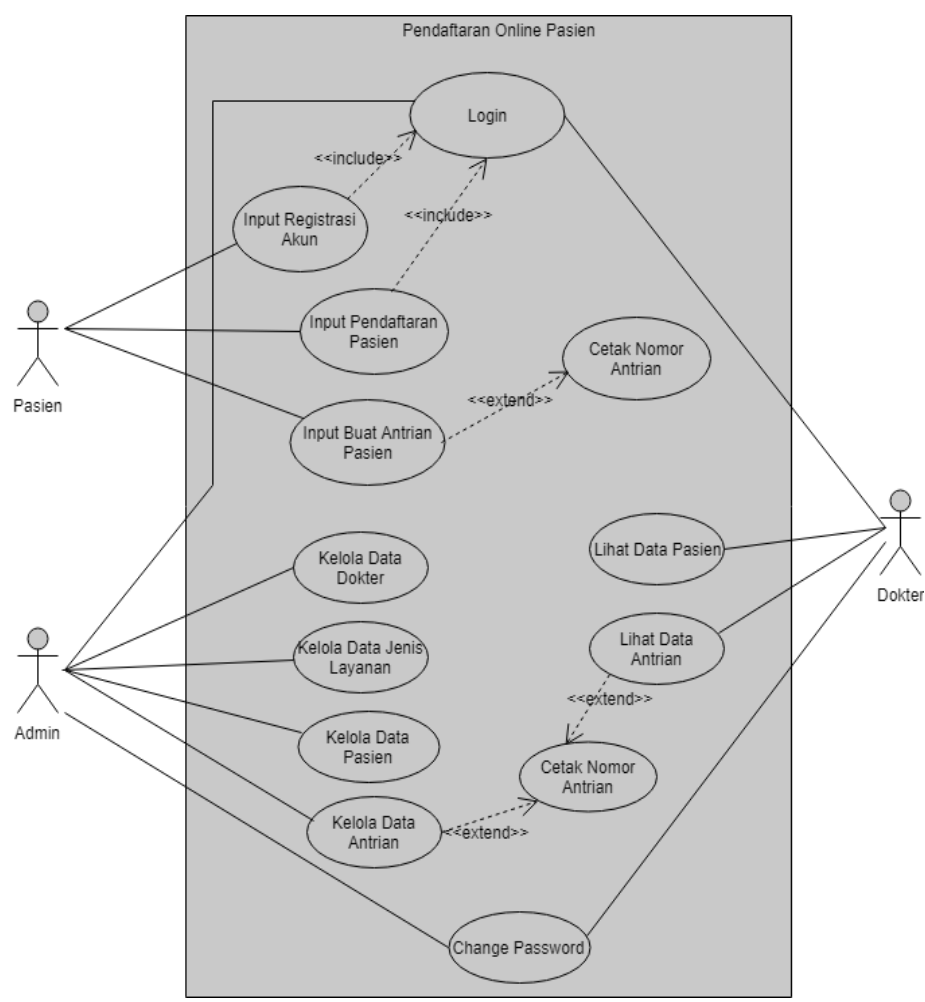

Gambar 2. Use Case Pendaftaran Online Pasien

Gambar diatas merupakan Use Case Diagram yang menggambarkan sistem secara keseluruhan. Terdapat menu Login, Input Registrasi Akun, Input Pendaftaran Pasien, Input Antrian Pasien, Cetak Nomor Antrian, Data Dokter, Data Jenis Layanan, Data Psien dan Data Antrian.

\section{b. Activity Diagram Input Pendaftaran Pasien}

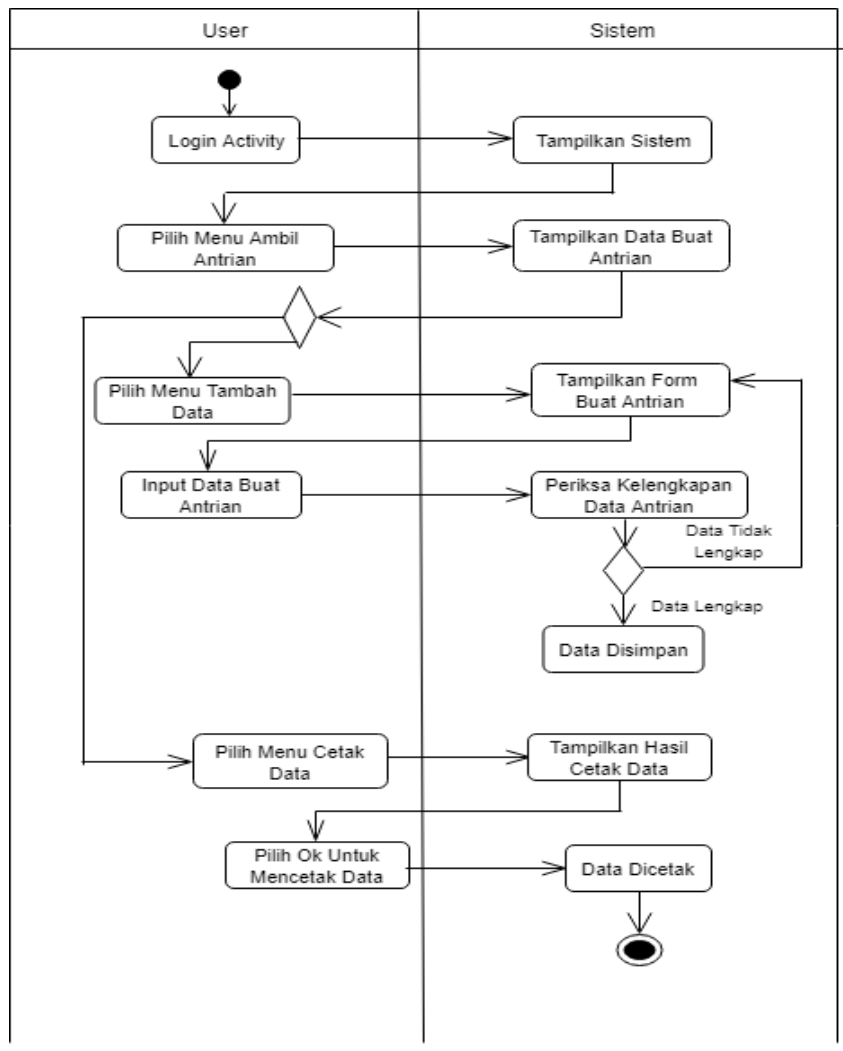

Gambar 3. Activity Diagram Input Pendaftaran Pasien 
Pada gambar di atas menjelaskan aktivitas yang terjadi pada sistem ketika user membuat data antrian. Prosedur diawali dengan user login, kemudian mengisikan data yang diperlukan untuk membuat antrian dan mencetak data antrian.

\section{c. Tampilan Antar Muka (User Interface)}

1. Tampilan Halaman Utama

Gambar berikut merupakan tampilan halaman Menu Utama dalam sistem. Terdapat menu Home, Profil, Fasilitas \& Layanan, Kontak dan Ambil Antrian.

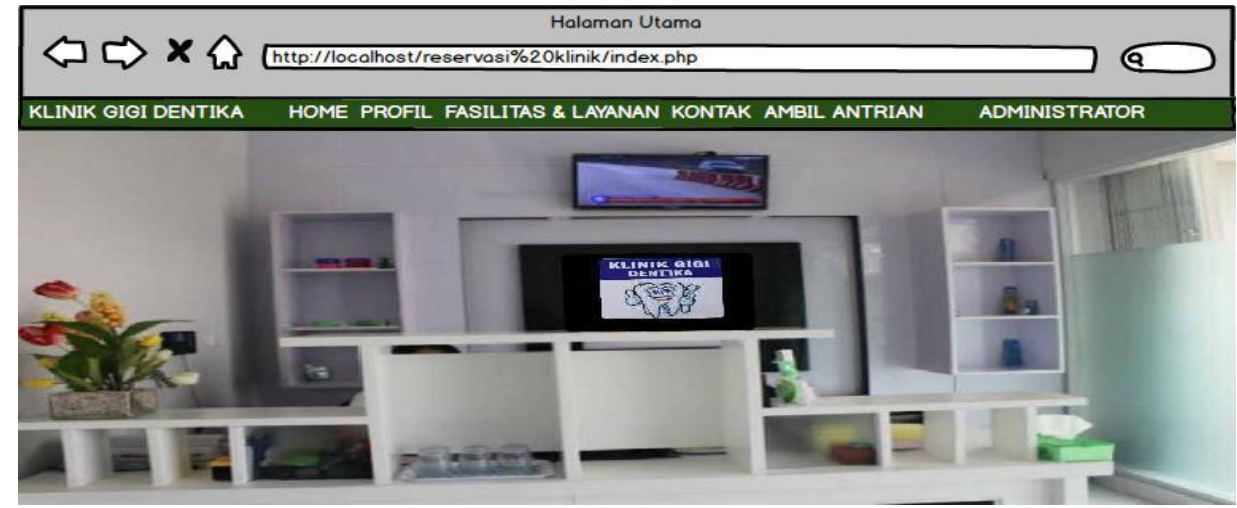

Gambar 4. Tampilan Halaman Menu Utama

2. Tampilan Halaman Login Administrator

Berikut merupakan tampilan halaman Login Admin. Langkah pertama adalah memilih Hak Akses, kemudian memasukan Username dan Password yang sesuai untuk masuk ke halaman utama Administrator.

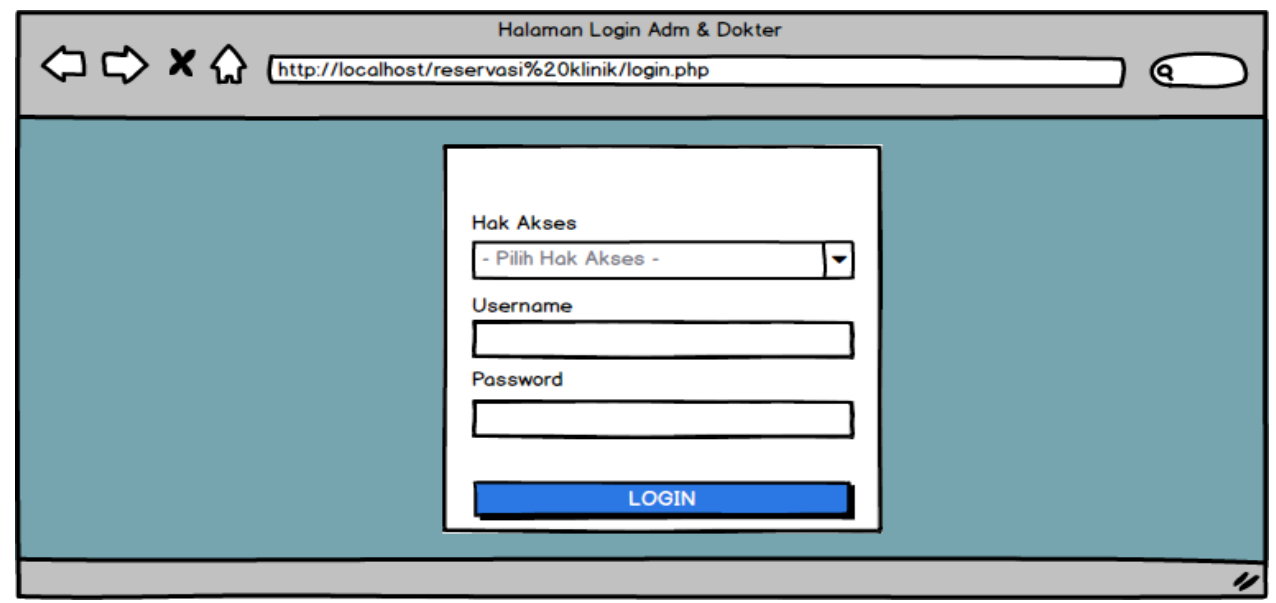

Gambar 5. Tampilan Halaman Login Admin

3. Tampilan Halaman Utama Administrator

Pada halaman Administrator terdapat menu Data Pasien, Data Dokter, Data Antrian dan lain-lain.

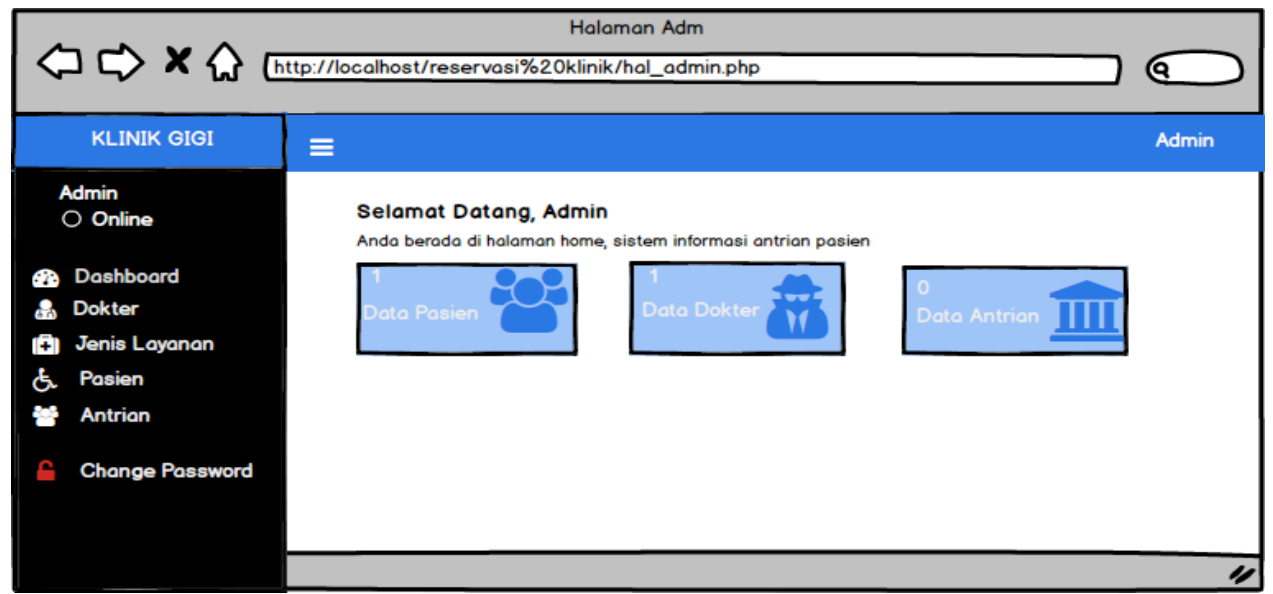

Gambar 6. Tampilan Halaman Administrator 
4. Tampilan Halaman Utama Dokter

Pada halaman ini, para dokter dapat login dan melihat data pasien dan data rekam medis pasien.

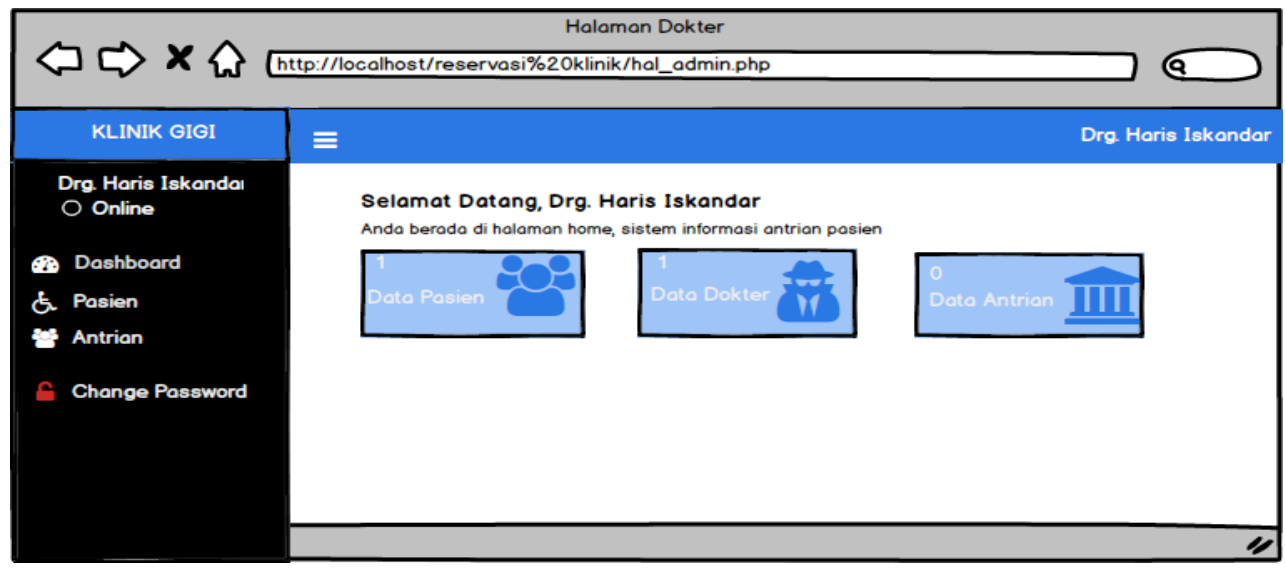

Gambar 7. Tampilan Halaman Utama Dokter

5. Tampilan Halaman Login dan Registrasi Pasien

Pada halaman ini, calon pasien dapat melakukan registrasi atau pendaftaran. Dan jika sudah mendaftar maka dapat membuat nomor antrian untuk melakukan pemeriksaan di Klinik Gigi Dentika.

\begin{tabular}{|c|c|}
\hline \multicolumn{2}{|c|}{ 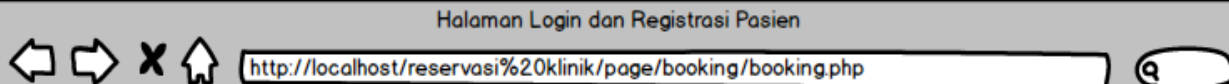 } \\
\hline KLINIK GIOI DENTIKA & HOME AMBIL ANTRIAN \\
\hline $\begin{array}{l}\text { Login Untuk Ambil Antrian dan Pengobatan } \\
\text { \& Perawatan Gigi }\end{array}$ & $\begin{array}{l}\text { Silahkan Daftar Disini } \\
\text { jikaanda belum mendaftarkan sebelumnyo }\end{array}$ \\
\hline Masukan NIK & NIK \\
\hline Password & Nama Pasien \\
\hline & Tempat Lahir \\
\hline LOGIN & \\
\hline & Tanggal Lahir \\
\hline & $\mathrm{mm} / \mathrm{dd} /$ yyyy \\
\hline
\end{tabular}

Gambar 8. Halaman Buat Antrian dan Cetak Nomor Antrian

6. Tampilan Halaman Cetak Nomor Antrian

Pada halaman ini pasien dapat melihat tampilan nomor antrian dan mencetak nomor antrian.

\begin{tabular}{|c|c|c|}
\hline KLINIK GIOI DENTIKA & & LOG OUT \\
\hline $\begin{array}{l}\text { Buat Antrian Pengobatan \& Perawatan } \\
\text { Gigi }\end{array}$ & \multicolumn{2}{|c|}{ Cetak Nomor Antrian } \\
\hline No. Telepon & No Antrian & : \\
\hline Tanggal Berobat & NIK & : \\
\hline $\mathrm{mm} / \mathrm{dd} / \mathrm{yyyy}$ & Nama & : \\
\hline Jam & No Telepon & \\
\hline \begin{tabular}{|l|}
$-\cdots$ \\
\end{tabular} & Tanggal & $: \mathrm{mm} / \mathrm{dd} / \mathrm{yyyy}$ \\
\hline Jenis Layanan & Jam & : 0:00 AM \\
\hline \begin{tabular}{|l}
- Pilih Layanan - \\
\end{tabular} & Jenis Layanan & : \\
\hline \begin{tabular}{|l|} 
LOGIN \\
\end{tabular} & & \begin{tabular}{|l|} 
Cetak No Antion \\
\end{tabular} \\
\hline
\end{tabular}

Gambar 9. Halaman Cetak Nomor Antrian 


\subsection{Hasil Pengujian}

Hasil Pengujian Black Box Pada Halaman Antrian

Tabel 1. Tahap Pengujian Antrian

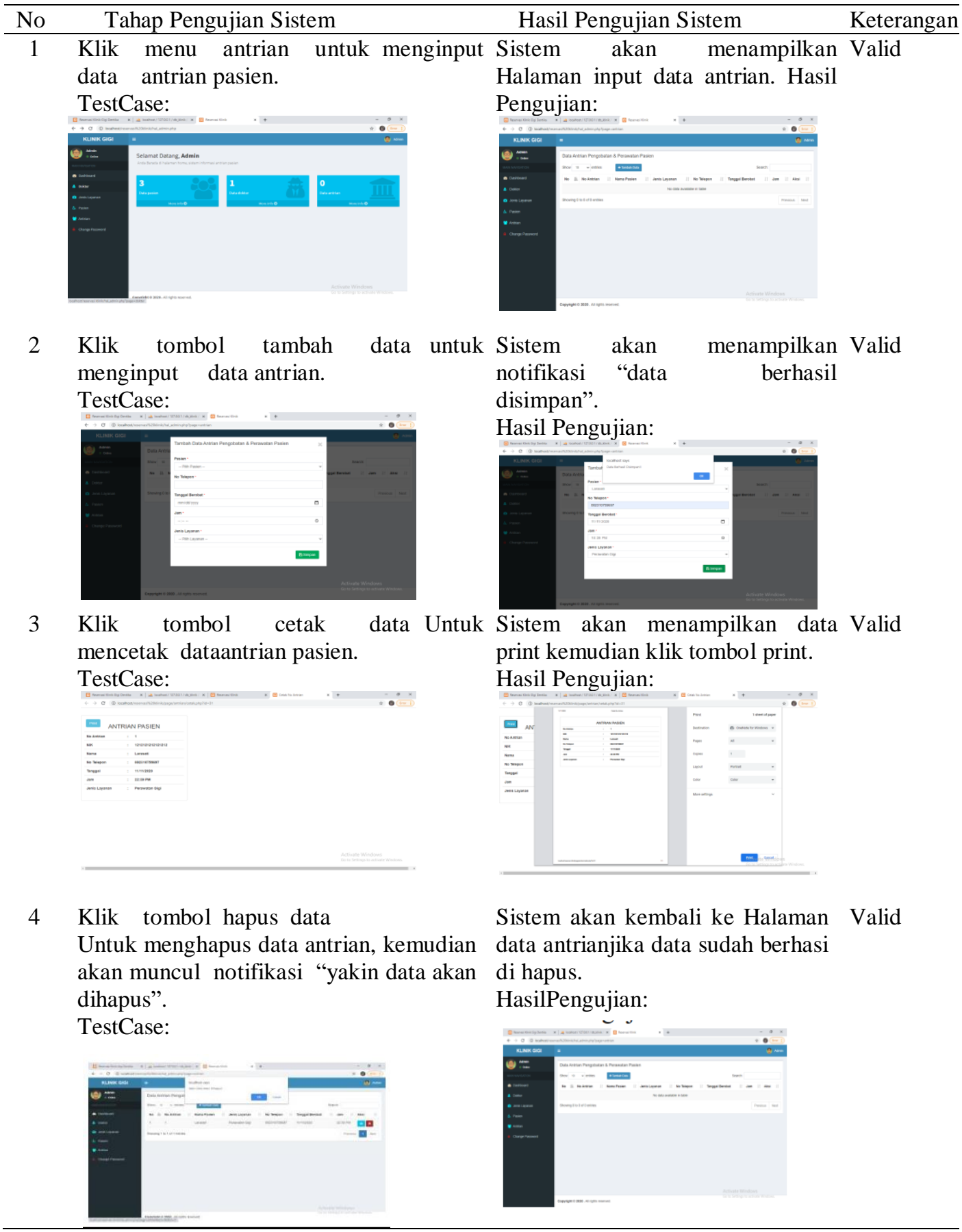

\section{KESIMPULAN}

Berdasarkan penelitian yang telah dilakukan terhadap Klinik Gigi Dentika, tentang sistem pendaftaran antrian pasien berbasis web dengan metode UCD ini mendapatkan hasil sebagai berikut: Berdasarkan pendekatan dengan metode UCD didapatkan solusi berupa fasilitas pendaftaran antrian pasien secara online melalui website sehingga mengurai kepadatan dan antrian saat proses pendaftaran secara online. Pasien pun dapat memilih jadwal sesuai kebutuhan sehingga tidak perlu menunggu lama di klinik. Bagian administrasi pun dapat dengan mudah membuat laporan berdasarkan data pendaftaran antrian yang ada di database. Sehingga laporan dengan mudah tersaji menjadi lebih efektif dan efisien. 


\section{REFERENCES}

[1] N. Rodiana, F. Akbar, and A. Sayfulloh, "Rancang Bangun Sistem Informasi Pelayanan Pasien Berbasis Web pada Klinik Gigi Lily Jakarta Barat,” Simp. Nas. Ilmu Pengettahuan dan Teknol. 2017, pp. 184-189, 2017.

[2] R. Septia Sari, "Pengelolaan Data Rekam Medis Melalui Sistem Penomoran Dan Penyimpanan Untuk Meningkatkan Mutu Pelayanan Kesehatan Di Klinik Gigi Dan Umum Puri Medical,” LOGISTA - J. Ilm. Pengabdi. Kpd. Masy., vol. 3, no. 2, p. 135, 2019.

[3] A. D. Kameswara, Y. Christyono, and R. R. Isnanto, "Klinik Gigi,” Transient, vol. 2, no. 3, pp. 672-679, 2013.

[4] I. S. Yatana Saputri, M. Fadhli, and I. Surya, "Penerapan Metode UCD (User Centered Design) Pada E-Commerce Putri Intan Shop Berbasis Web,” J. Nas. Teknol. dan Sist. Inf., vol. 3, no. 2, pp. 269-278, 2017.

[5] S. Supardianto and A. B. Tampubolon, "Penerapan UCD (User Centered Design) Pada Perancangan Sistem Informasi Manajemen Aset TI Berbasis Web di Bid TIK Kepolisian Daerah Kepulauan Riau," J. Appl. Informatics Comput., vol. 4, no. 1, pp. 74-83, 2020.

[6] Rosa dan Shalahuddin, Rekayasa Perangkat Lunak Terstruktur dan Berorientasi Objek. Bandung: Informatika, 2011.

[7] J. Simarmata, Rekayasa Perangkat Lunak. Yogyakarta: Andi, 2010.

[8] Munawar, Analisis Perancangan Sistem Berorientasi Objek dengan UML: Unified Modeling Language. Bandung: Informatika, 2018. 